УДК 94(47).031

DOI: $10.22378 / 2313-6197.2017-5-2.344-351$

\title{
SUCCESSION TO THE THRONE IN THE GOLDEN HORDE: REPLACEMENT OF THE BATUIDS BY THE TUQAI-TIMURIDS
}

\author{
I.M. Mirgaleev \\ Sh. Marjani Institute of History of Tatarstan Academy of Sciences \\ Kazan, Russian Federation \\ dilnur1976@mail.ru
}

Research objectives: To find out both the principle of succession to the throne in the Golden Horde after the extinction of Batuid family - the ruling dynasty line of the Jochids - and the reasons for the rise of the Tuqai-Timurids.

Research materials: In his analysis, the author is based on the genealogical sources and compares them with the Arab-Persian historical works and chronicles.

Results and novelty of the research: After the death of Berdibek, the principle of succession in the Golden Horde was disrupted since the Batuid family ceased to exist. The remaining Jochid families had to decide whose line will have had the right to sovereignty. The Time of Troubles of the 1360-70s ended with a Tuqai-Timurid Tokhtamysh's victory. Replacement of the Batuids by the Tuqai-Timurids was in effect only during the reign of khan Tokhtamysh and therefore it can not be regarded as definitive and generally accepted solution to the problem. In addition to the Tuqai-Timurids, also representatives of the Shibanids will have become khans in the Turko-Tatar yurts in the future. It was precisely the process of disintegration of the Golden Horde and the unsolved problem of succession that led to the fact that hereinafter "any" Jochid could lay claim to the throne in postGolden Horde yurts.

Keywords: Golden Horde, succession to the throne, Tuqai-Timurids, Batuids, Jochids

For citation: Mirgaleev I.M. Succession to the Throne in the Golden Horde: Replacement of the Batuids by the Tuqai-Timurids. Zolotoordynskoe obozrenie $=$ Golden Horde Review. 2017. Vol. 5, no. 2, pp. 344-351. DOI: 10.22378/2313-6197.2017-5-2.344-351

We can often find the statement in the academic literature that allegedly all the Chinggisids had a right to the throne. Somebody can justify this assertion quoting the statement pronounced by Chinggis Khan himself in the family council after Ögedei had asked a question regarding the future descendants and heirs. According to the "Secret History", Chinggis Khan replied that someone would always found among his descendants, who would be able to run the country: "Can it be true that no suitable heir to be born among my descendants?" [12, p. 138]. However, although Chinggis Khan had also other sons from other wives and concubines (whose number amounted to as much as 400 ), already during his lifetime only sons from Borte, his first wife, became "khans" [10, p. 106a; 11, p. 677]. In addition, Chinggis Khan appointed Ögedei his only heir on the family council: Jochi and Chagatai should have served Ögedei [12, p. 137]. Neither all the sons of Chinggis Khan's firstborns could for the future occupy the throne in their uluses. As it is known, from fifteen Jochi's sons [8, p. 60] only the descendants of Batu became khans. Perhaps, if Berke had children, his descendants would have become the ruling dynasty. But even in this case, other Jochids would not have been able to claim the throne. In turn, by the middle of the $14^{\text {th }}$ century the only Jochids who 
possessed political power were the descendants of the Jochi's sons Shiban and Tuqai-Timur. It is quite possible that there were also descendants of other Jochids since it is unlikely that among the numerous sons of Jochi only Shiban and TuqaiTimur had offspring. However, they were not able to lay claim to the throne, and perhaps they did not have the right to do so. The winner must always be one. Representative of the Jochi younger son's, Tuqai-Timur's family, khan Tokhtamysh could ascend after both Batu family's extinction and the political turmoil that followed that, where enthronement of Khan, which would be recognized by all, became a major issue of political struggle.

Tuqai-Timurids' ascension's issue remains complex and related to Uzbek Khan's reform of succession principle in the Golden Horde, when Uzbek attempted to transform the generic inheritance of the supreme power in the dynastic one [7]. This question was also related to political turmoil that plagued the Jochid ulus in the 1360-70s, when the Tatar elite faced a difficult choice whether to return to the generic principle of succession or continue to adhere to the tradition of dynastic succession introduced by Uzbek Khan. For this it was necessary that all the Jochids would have recognized the right of one among their lines to a supreme power: to replace the Batuids with the Tuqai-Timurids or the Shibanids. It is also possible that the right of other lines was taken up for consideration. Despite the fact that their presence raises doubts, according to indirect data and some historical writings, descendants of Orda Ichen and, possibly, descendants of Jochi's son Tangut might have been among the contenders for power [9, p. 209].

However, since a natural succession by the Batuids was disrupted with both Batuid family's extinction after Berdibek's death and the recognition of this fact by other Jochids, the remained Jochids faced a question: whose line will be eligible for the supreme power? In spite of the rise to power of some "youths" from the Batuids after Berdibek's death, during the first two years, the political elite did not realize these questions completely. That is, the country was not ruled by the Jochids but by emirs. Only the rulers of the left wing were the exception. Khyzyr Khan from the Shibanids, the Ordaids or the Tuqai-Timurids was the last khan of the united Golden Horde, who was recognized by all the emirs $[5$, p. $37 ; 14$, p. 130]. In turn, the Jochid ulus was divided into two parts after the murder in 1362 of Kildibek Khan [6, p. 35]. That is, the intensity of the struggle for power reached its peak and, at least, the strong Jochid families reclaimed their rights to the throne. After the Kildibek's death, the need to replace the Batuids, who had already ceased to exist, by another Jochid family became obvious to all. From that time many Jochids became "legitimate" contenders to the throne, as the rulers of the left wing and Ak Horde and Saray emirs were unable to confirm the right to the throne for a specific Jochid. After Khyzyr Khan's death, everybody joined the struggle for succession: both the influential head of the clans and the descendants of Jochi. In order to secure the Golden Horde throne for one of the Jochid families, one of these families now had to emerge victorious from this struggle.

During the turmoil that followed the death of Berdibek, representatives of the Tuqai-Timurids certainly were among the contenders for power $[14, \text { p. 61] }]^{1}$. Emirs

${ }^{1}$ A.Gaev's assertion supported by V. Kostyukov, that the khans of Mamai Horde were from the Tuqai-Timurids (as well as the assertion that Ordu-Melik was a Tuqai-Timurid), requires a serious analysis of their arguments [3; 4]. In my opinion, these claims can not be accepted as a proven yet and needs further study. 
of Ak Horde nominated the "youths" from the Batuid line who certainly had some kinship with the Batuids (perhaps through the female line), but their legitimacy was still in question. Also the Shibanids and the Tuqai-Timurids advanced their claims to the throne. In addition, representatives of these families were the ulusbeks. Moreover, these two families supported each other. For example, it became evident at the time of a Tuqai-Timurid Toktamysh's rise, who was actively supported by the Shibanids.

Why it were the Tuqai-Timurids who ascended? We believe that it is possible to put forward a few suggestions. Undoubtedly, the Tuqai-Timurids were influential and had their own ulus and family connections with the leading clans: the Kungrats, the Shirins, the Kypchaks, etc. Perhaps, the Tuqai-Timurids came to the defense of greatness and unity of the Golden Horde during the political turmoil of the $14^{\text {th }}$ century following the death of Berdibek, because in addition to their native ulus they represented a kind of support of the ruling family - the house of Batu - may be, on the rights of the descendants of Jochi's youngest son. As is known, Jochi had many wives and concubines. Tuqai-Timur was the youngest among his brothers or was considered as such according to his mother's rank. For example, although Ögedei became the Mongol Empire's Kaghan after Chinggis Khan, however Tolui as the youngest son of Chinggis Khan, was the keeper of the Chinggisid family hearth. When Ögedei was declared the Chinggis Khan's heir and his older brothers Jochi and Chagatai should have "serve" him while remaining the rulers of their own uluses, then their younger brother Tolui said that "I will dwell near that of an older brother indicated by our father-Emperor. I will remind him that he will have forgotten. I will wake him if he would sleep for a long time. I will be his echo. I will be a whip for his red horse. I will not delay to obey him and will not violate the order" [12, p. 137-138]. That is, functions of the youngest son were identified in the family council in accordance with the Turko-Mongol customs: youngest son always remained in his father's house and became the custodian of a family. In turn, when the "youngest son's" functions were applied to the entire state, then he became the custodian of order, tradition and dynasty. If we assume the existence of such functions in the "family of Jochi" as well, then it may explain why the Shibanids provided full support to the Tuqai-Timurids, although, at first glance, the Shibanids enjoyed a superior position according to their hierarchical status within the Jochid dynasty. In our opinion, the Tuqai-Timurids were the keepers of the "Jochi's hearth" and therefore they should not be considered as mere ulusbeks, as were, on the contrary, both the early Ordaids and Shibanids as well as the other Jochids. Of course, they also had their own ancestral ulus located close enough to Saray. Undoubtedly, their relations with Saray were not only close but embodied with something outstanding and indicating their special position in relation to the whole house of Jochi.

Judging by the fact that Tokhtamysh sought to restore the unity of the Golden Horde of Uzbek Khan's times and he succeeded in this, it becomes clear that also in the dynastic issue, he and his entourage sought to assert the right to the throne of one of the Jochid families. Perhaps, by doing this, he pointed out that the TuqaiTimurids were the "keepers of the Jochid family (or the state)". That is, they set about to establish the order in the state. In this way they strengthened their position compared with the other Jochids. 
The accession to power and, most importantly, securing of the throne for one of the Jochid families for many years became possible only thanks to the constant support of the clans. Only those of the Jochid families who had in their service strong and functioning els-clans, would have been able to assert their authority throughout the territory of the state. The fact that the Tuqai-Timurids were able to affirm their els throughout the state, explains their success and victory over the rest of the Jochids.

While reinforcing their influence, the Tuqai-Timurids also strengthened their els in every possible way. The Kiyats and the Kungrats, the main operating clans before and during the turmoil, left the political scene, and new clans - the Shirins, the Argyns, the Kypchaks, and the Baryns - took their place thanks to Tokhtamysh. The Mangyts already became, essentially, a tribal union, as they remained among the nomads. In turn, the Kungrats and the Kiyats were completely exhausted during the turmoil and war with Aksak Timur. Of course, they remained present, but in order to be at the top of the political elite, several preconditions are required. After all, in the very days of Chinggis Khan, these clans were given the right to marry the representatives of the Golden Family. In our opinion, there were several reasons for their weakening.

Firstly, there were no strong representatives of these clans among the winners - supporters of a Tuqai-Timurid Tokhtamysh (this applied particularly to the Kiyats), since many of them were killed in internecine collisions during the political turmoil and, particularly, during the decade-long war with Timur (the latter applied especially to the Kungrats).

Secondly, new contenders for power were in need of permanent servicemen and khans, therefore, surrounded themselves with members of other clans who received immense allotments of land and immune rights in exchange for the service of khan. Before Tokhtamysh, the Golden Horde khans bestowed tarkhan privileges mainly on the clergy. But after liquidation of kurultais in the reign of Uzbek Khan and establishment of khan's hereditary power, a ruler was in need of more and more people who would have dedicated themselves to the service of the head of state receiving for exchange land in fief and a variety of immune rights. According to G. Fedorov-Davydov, before Toktamysh, tarkhan grants were not very common throughout the state [16, p. 125].

The pace of political change was enormous and former elite clans deprived of their leaders, were unable to reproduce new powerful and, most importantly, capable personalities. Although the clan structure depends on the individuals, however, in order that direct clan leaders were influential and successful, el must be strong and be ruled by several strong personalities - by brothers and cousins of the clan leader, etc. That is, the clan must not only be ready to serve the Khan, but also be large enough.

Given the fact that the clans formed the army, it becomes clear that in order to comply with the above requirements, there was need of sufficiently strong functioning clan system.

The Tuqai-Timurids came to power relying on their els. In turn, at first the Kungrats greatly supported Tokhtamysh ${ }^{2}$ both in the 1370s during his struggle for

\footnotetext{
2 "Anonymous of Iskander" and Muhammad Ghaffari report that Kui-Kichik (according to “Anonymous of Iskander" - Kutan-Kunchek) from Kungrat tribe was Tokhtamysh's mother [14, p. 132, 211]. Undoubtedly, such a kinship was very helpful for Tokhtamysh.
} 
the throne against the other contenders as well as in time of war with Timur, where they lost the bulk of their clan. For their part, after Mamai's death, the Kiyats took no action against Tokhtamysh either independently, or at the time of Bek-Bulat's rebellion, nor during Tokhtamysh's struggle with Edigu. Their clan was captured by Timur and destroyed [14, p. 115], whereupon they were not able to revive. For example, in the late Golden Horde and the Tatar khanates they were not already represented in divan.

In turn, in the late Golden Horde Tatar khanates new els-clans - the Shirins, the Argyns, the Kypchaks, and the Baryns - took the lead of the former Golden Horde Karachi-beys' system ${ }^{3}$. The western part of the Golden Horde was more urbanized and was based on the rich previous Turkic foundation in the Volga region. As a result, it became an area of the active formation of the new nation of medieval Tatars. Exactly this part was able to preserve the cultural and political tradition of the Golden Horde.

We believe that Tokhtamysh's ideology - ideology of the unity and greatness of the country as well as purely dynastic and governmental one - last but not least, contributed to his victory. However, further Tokhtamysh was forced to rely primarily on his ancestral ulus system. Tuqai-Timurid ulus was not extensive and strong. However, Tokhtamysh would not have been able to find active supporters without relying on his ancestral ulus system. As is known, ulusbek relies on his els. Tokhtamysh likewise relied on his els, but throughout the entire state. If previously the Batuids relied on the Kiyats and the Kungrats, then Tuqai-Timurids relied on the els of their ancestral ulus.

Uzbek Khan introduced a new principle of succession of power from father to son. Uzbek's reform was aimed at strengthening the central government. However, this system could function successfully only if the ruling dynasty had a direct descendant in the male line. The crisis, in turn, arose after the death of khan Berdibek. Theoretically, other Jochid families could replace the reigning one if necessary. In practice, however, the usual enthronement even in the capital Saray could not cease the turmoil due to the emergence of more and more candidates. Political instability in the Jochid ulus of the $1360-70$ s was caused by internal dynastic struggle for the right to the throne.

Undoubtedly, already in the early period of the Jochid ulus many lines of the Jochid dynasty lost the right to the throne. This, of course, was in compliance with the norms of Turko-Mongol law. The Ordaid (?), Tuqai-Timurid and Shibanid families that strengthened during the turmoil ruled their uluses and had at their disposal the human and financial resources, which enabled them to fight for power. Tokhtamysh's relations with the Kungrat clan and influential emirs of Saray, Khwarezm and Kok Horde as well as support of the Shibanids and the skillful use of the capacity of his own ancestral els ensured Tokhtamysh's victory over the other contenders.

\footnotetext{
${ }^{3}$ Generally, in various Tatar khanates Karachi-beys represented several clans, such as: the Shirins, the Baryns, the Argyns, the Kypchaks, the Mangyts, the Jalayrs, the Mansurs, the Sejiuts, etc. [1, p. 209; 2, p. 411-420; 17, p. 674-675; 18, p. 45]. Most of these els belonged to the original Tuqai-Timurid ulus or they were the Tokhtamysh's supporters. Ötemish Hajji says in his "Chinggis-name" that "since the time of the ancestors, the Shirins, the Baryns, the Argyns, and the Kipchaks were the old Oglan Tokhtamysh's els", and when Tokhtamysh began "raiding the el" of Urus Khan, "bayards and dashing fellows from these els joined him as nökers and began to support him" [15, p. 115].
} 
After defeat from Aksak Timur, the Tuqai-Timurids who seemingly approved their right to the throne, were unable to retain the throne of Jochi. All of Tokhtamysh's sons were killed. Both the Shibanids and many Tuqai-Timurids began to contest the power. As a result, while not being able to unite under their command the entire Jochid ulus, these clans began to establish themselves as independent rulers creating thereby new states.

\section{REFERENCES}

1. Vel'yaminov-Zernov V.V. Issledovanie o Kasimovskikh tsaryakh i tsarevichakh [Study on the Kasimov Tsars and Tsareviches]. Part I. St. Petersburg, IAN Publ., 1863. (In Russian)

2. Vel'yaminov-Zernov V.V. Issledovanie o Kasimovskikh tsaryakh $i$ tsarevichakh [Study on the Kasimov Tsars and Tsareviches]. Part II. St. Petersburg, IAN Publ., 1864. (In Russian)

3. Gaev A.G. Genealogiya i khronologiya Dzhuchidov. K vyyasneniyu rodosloviya numizmaticheski zafiksirovannykh praviteley Ulusa Dzhuchi [Genealogy and Chronology of the Jochids. To Clarify the Genealogy of the Jochid Ulus' Rulers Recorded Numismatically]. Drevnosti Povolzh'ya i drugikh regionov. Numizmaticheskiy sbornik [Antiquities of the Volga Region and Other Regions. Numismatic Collection]. Is. IV. Vol. 3. Nizhny Novgorod, 2002, pp. 9-54. (In Russian)

4. Kostyukov V.P. Shibanidy i Tukatimuridy vo vtoroy polovine XIV v. [The Shibanids and the Tuqa-Timurids in the second half of the $14^{\text {th }}$ century]. Vestnik Chelyabinskogo gosudarstvennogo universiteta. 2009. No. 28 (166). Istoriya. Is. 34 [Bulletin of Chelyabinsk State University. 2009. No. 28 (166). History. Iss. 34], Chelyabinsk, pp. 39-43. (In Russian)

5. Materialy po istorii Kazakhskikh khanstv XV - XVIII vekov (Izvlecheniya iz persidskikh i tyurkskikh sochineniy) [Materials on the History of the Kazakh Khanates of the $15^{\text {th }}-18^{\text {th }}$ centuries (extracts from Persian and Turkic writings)]. Sostaviteli: S.K.Ibragimov, N.N.Mingulov, K.A.Pishchulina, V.P.Yudin. Almaty, «Nauka» Kazakh. SSR Publ., 1969. 652 p. (In Russian)

6. Mirgaleev I.M. Politicheskaya istoriya Zolotoy Ordy perioda pravleniya Toktamysh-khana [Political History of the Golden Horde during the Reign of Tokhtamysh Khan]. Kazan, Alma-Lit Publ., 2003. 164 p. (In Russian)

7. Mirgaleev I.M. Problema prestolonaslediya v period smuty v Zolotoy Orde (60-70-e gody XIV veka) [The Problem of Succession to the Throne during the Period of Turmoil in the Golden Horde (the 1360-70s)]. Dialog gorodskoy i stepnoy kul'tur na evraziyskom prostranstve. Materialy IV Mezhdunarodnoy konferentsii, posvyashchennoy pamyati professora MGU G.A. Fedorova-Davydova 30 sentyabrya - 3 oktyabrya 2008 goda. Azov, 2009 g. [Dialogue between Urban and the Steppe Cultures on the Eurasian Space. Proceedings of the IV International Conference dedicated to the memory of Professor of Moscow State University, G.A. Fedorov-Davydov, $30^{\text {th }}$ September $-3^{\text {rd }}$ October, 2008. Azov, 2009]. Donskie drevnosti [The Don River Antiquities]. Is. 10, pp. 348-358. (In Russian)

8. Mirgaleev I.M. «Shuab-i pandzhgana» Rashid ad-dina: perspektivy izucheniya [Rashid al-Din's "Shuab-i Pandjghana": Research Perspectives]. Zolotoordynskoe obozrenie $=$ Golden Horde Review. 2013, no 1, pp. 57-64. (In Russian)

9. Pochekaev R.Yu. Mamay: Istoriya "antigeroya»v istorii (630-letiyu Kulikovskoy bitvy posvyashchaetsya) [Mamay: Story of "Anti-Hero" in History (dedicated to the $630^{\text {th }}$ anniversary of the Battle of Kulikovo)]. St. Petersburg, EVRAZIYa Publ., 2010. 288 p. (In Russian) 
10. Rashid al-Din. "Shuab-i pandzhgana”. Faksimile ["Shu'ab-i Panjganah". Facsimile]. Podgotovka k izdaniyu k.i.n. I.M.Mirgaleev. Kazan, Sh.Marjani Institute of History of Tatarstan Academy of Sciences Publ., 2016. 460 p. (In Persian)

11. Rashid al-Din. Shuab-i pandzhgana. 2. Mongoly i tyurki (1) [Shu'ab-i panjganah. 2. The Mongols and Turks (1)]. Zolotoordynskoe obozrenie=Golden Horde Review. Kazan, 2016. Vol. 4, no. 3, pp. 668-680. (In Russian)

12. Sokrovennoe skazanie mongolov [The Secret History of the Mongols]. Perevod S.A. Kozina. Moscow, Tovarishchestvo nauchnykh izdaniy KMK, 2002. 156 p. (In Russian)

13. Tiesenhausen V.G. Sbornik materialov, otnosyashchikhsya $k$ istorii Zolotoy Ordy. Tom I. Izvlecheniya iz sochineniy arabskikh [Collection of Materials Related to the Golden Horde History. Vol. I. Extracts from Arab Writings]. St. Petersburg, IAN Publ., 1884. 564 p. (In Russian)

14. Tiesenhausen V.G. Sbornik materialov, otnosyashchikhsya k istorii Zolotoy Ordy. Vol. II. Izvlecheniya iz persidskikh sochineniy sobrannye V.G.Tizengauzenom $i$ obrabotannye A.A.Romaskevichem i S.L.Volinym [Collection of Materials Related to the Golden Horde History. Vol. II. Extracts from Persian Writings Collected by V.G. Tiesenhausen and Processed by A.A.Romaskevich and S.L.Volin]. Moscow, Leningrad, Akademiya nauk SSSR Publ., 1941. 308 p. (In Russian)

15. Ötemish-Hajji. Chingiz-name [Chinggis-name]. Per. V.P. Yudina. Almaty, Gylym Publ., 1992. 296 p. (In Russian)

16. Fedorov-Davydov G.A. Obshchestvennyy stroy Zolotoy Ordy [Social System of the Golden Horde]. Moscow, Moscow State University Publ., 1973. 180 p. (In Russian)

17. Khudyakov M.G. Ocherki po istorii Kazanskogo khanstva [Essays on the History of the Kazan Khanate]. Na styke kontinentov $i$ tsivilizatsiy... (iz opyta obrazovaniya $i$ raspada imperiy $X-X V I v v$.) [At the Crossroads of Continents and Civilizations ... (from experience of formation and collapse of empires in the $10^{\text {th }}-16^{\text {th }}$ centuries)]. Moscow, Insan Publ., 1996, pp. 527-764. (In Russian)

18. Schamiloglu Yu. «Karachi bei» pozdney Zolotoy Ordy: Zametki po organizatsii mongol'skoy mirovoy istorii ["Karachi-Beys" of the Late Golden Horde: Notes on the Organization of the Mongol World History]. Iz istorii Zolotoy Ordy [From the Golden Horde History]. Kazan, Fond im. M. Sultan-Galieva, 1993, pp. 44-60. (In Russian)

About the author: Il'nur M. Mirgaleev - Cand. Sci. (History), Head of the Usmanov Center for Research on the Golden Horde and Tatar Khanates, Sh.Marjani Institute of History of Tatarstan Academy of Sciences, ORCID: http://orcid.org/0000-0001-6013-6944, Researcher ID : J-9533-2017 (7, Baturin Str., Kazan 420111, Russian Federation). E-mail: dilnur1976@mail.ru 
Mirgaleev I.M. Succession to the Throne in the Golden Horde...

\title{
ПРЕСТОЛОНАСЛЕДИЕ В ЗОЛОТОЙ ОРДЕ: ЗАМЕНА БАТУИДОВ НА ТУКАЙТИМУРИДОВ
}

\author{
И.М. Миргалеев \\ Институт истории им. Ш. Марджани АН РТ \\ Казань, Российская Федераичи \\ dilnur1976@mail.ru
}

Цель: выяснить принцип престолонаследия в Золотой Орде после прекращения рода Батуидов, правящей линии династии Джучидов, и причины возвышения Тукайтимуридов.

Материаль исследования: в своем анализе автор основывается на генеалогических источниках в сопоставлении с арабо-персидскими историческими сочинениями и хрониками.

Результаты и научная новизна: после гибели Бердибека принцип престолонаследия в Золотой Орде был нарушен, так как род Батуидов прекратил свое существование. Остальным Джучидским родам было необходимо решить: чья линия будет иметь право на верховную власть? Смута 60-70-х годов XIV века закончилась победой Тукайтимурида Токтамыша. Замена Батуидов на Тукайтимуридов функционировала только во время правления Токтамыш-хана и поэтому не может рассматриваться как вопрос решенный и общепринятый. В будущем ханами в тюрко-татарских юртах кроме Тукайтимуридов становились и представители Шибанидов. Именно процесс распада Золотой Орды и нерешенность престолонаследия привели к тому, что в дальнейшем «любой» Джучид мог претендовать на трон в постзолотоордынских юртах.

Ключевые слова: Золотая Орда, престолонаследие, Тукайтимуриды, Батуиды, Джучиды

Для цитирования: Mirgaleev I.M. Succession to the Throne in the Golden Horde: Replacement of the Batuids by the Tuqai-Timurids // Золотоордынское обозрение. 2017. T. 5, № 2. C. 344-351. DOI: 10.22378/2313-6197.2017-5-2.344-351

Сведения об авторе: Ильнур Мидхатович Миргалеев - кандидат исторических наук, руководитель Центра исследований Золотой Орды и татарских ханств им. M.A. Усманова Института истории им. Ш. Марджани AH PT, ORCID: http://orcid.org/0000-0001-6013-6944, Researcher ID : J-9533-2017 (420111, ул. Батурина, 7, Казань, Российская Федерация). E-mail: dilnur1976@mail.ru 